\title{
Comparison of concanavalin A reactive determinants on isolated haemocytes of parasite- infected and non-infected freshwater crayfish
}

\author{
Mutsuo Kobayashi*, Kenneth Söderhäll** \\ Department of Physiological Botany, The University of Uppsala, Box 540 S-751 21 Uppsala, Sweden
}

\begin{abstract}
The specific binding of concanavalin A (Con A) to semigranular (SG) and granular (G) cells of the crayfishes Pacifastacus leniusculus and Astacus astacus was shown by in vitro agglutination of fixed haemocytes and by direct labelling with fluorescein isothiocyanate-conjugated Con A (FITCCon A). When non-fixed cell monolayers from both species of crayfish were treated with FITC-Con $A$, capping of $G$ cells was observed and nearly all of the SG cells showed patching. The percentage of capforming G cells from Psorospermium haeckeli-infected $A$. astacus was clearly higher than that of noninfected crayfish. Also in the signal crayfish $P$. leniusculus which carries the crayfish plague parasite Aphanomyces astaci within the cuticle, a high percentage of cap-forming $G$ cells was present. In $A$. astacus which received a Zymosan injection, a higher percentage of cap formation of $G$ cells was observed compared with that of control crayfish. These results show that the presence of parasites alters the binding pattern of Con $A$ to the haemocyte surface and this altered binding pattern suggests that these cells have become activated for cellular defence reactions within the host haemolymph.
\end{abstract}

\section{INTRODUCTION}

In invertebrates haemocytes play an important role in the defence against invading parasites and pathogenic or non-pathogenic micro-organisms that might enter the haemocoele through wounds of the cuticle or alimentary canal (for reviews see Ratcliffe \& Rowley 1979, Söderhäll \& Smith 1986, Lackie 1988). In crayfish, with the development of a method to fractionate subpopulations of blood cells (Söderhäll \& Smith 1983 ) it is now possible to analyse the in vitro response of haemocytes against foreign objects (Persson et al. $1987 b)$ and also to test the biological activity of the purified components of the prophenoloxidase activating system (Johansson \& Söderhäll 1988, 1989a, b, Kobayashi et al. 1990). Recently, staining of haemocytes with fluorescein isothiocyanate (FITC)-labeled lectins have shown that some of the haemocytes involved in encapsulation reactions in Drosophila

\footnotetext{
- Present address: Department of Medical Zoology, Dokkyo University School of Medicine, Mibu, Tochigi 321-02. Japan

- Addressee for reprint requests and corresponding author
}

melanogaster altered their surface properties (Rizki \& Rizki 1983, Nappi \& Silver 1984). Moreover, Nappi \& Christensen (1986) also showed some alteration of haemocyte surfaces using FITC-labelled wheat germ agglutinin (WGA) when microfilariae were introduced into the thorax of mosquitoes. However, a direct correlation between the change of haemocyte surfaces and increased degree of encapsulation or phagocytosis has not been demonstrated. This study has been performed to compare whether haemocytes of parasite-infected and parasite-free crayfish have altered surface properties as has been previously demonstrated in insects (Rizki \& Rizki 1983, Nappi \& Silver 1984, Nappi \& Christensen 1986). We have used Psorospermium haeckelii-infected Astacus astacus and Pacifastacus leniusculus exosketally infected by the plague fungus Aphanomyces astaci. As controls, non-infected A. astacus were used since disease-free $P$. leniusculus can not be obtained.

Both parasites are severe threats to crayfish in their natural environment, and even more so during aquaculture activities (Söderhäll 1988). In Europe the crayfish Pacifastacus leniusculus has been introduced into many waters to replace the native populations of fresh- 
water crayfish which have been eradicated from many waters by the fungal parasite Aphanomyces astaci. However, since $P$. leniusculus carries the crayfish plague fungus $A$. astaci in their cuticle as a latent infection it functions as a vector for this disease (Persson et al. 1987a, Söderhäll et al. 1988), but more importantly it can easily die from the parasite if the host immune system is decreased in efficiency (Persson et al. 1987a).

This investigation was carried out to compare the haemocyte behaviour of isolated and separated haemocytes from parasite-infected and non-infected crayfish using an in vitro assay system. Since it has been impossible to obtain disease-free Pacifastacus leniusculus we have used separated haemocytes from disease-free Astacus astacus as controls. The different haemocyte types from these 2 representatives of the Astacidae are morphologically and functionally identical (Smith \& Söderhäll 1983, Johansson \& Söderhäll 1985, 1988, 1989a, b, c, Söderhäll et al. 1988) thus making an in vitro comparison of haemocyte behaviour, using isolated and separated haemocytes, valid. By using a lectin as a ligand we show that haemocytes of parasite-infected crayfish bind this lectin to the haemocyte surface in a manner similar to vertebrate lymphocytes (i.e. capping). Cap-formation in vertebrate lymphocytes is often a first sign that the cells are activated to produce for example antibodies, and therefore, our results indicate that the haemocytes of plague-infected $P$. leniusculus and Psorospermium haeckelii-infected $A$. astacus are in an active form at least compared to haemocytes of disease-free crayfish.

\section{MATERIALS AND METHODS}

Crayiish. Freshwater crayfish Pacifastacus leniusculus were collected from lake Halmsjön, Uppland, Sweden, and Astacus astacus from Ölandskräftan AB or Kroab AB, Sweden. They were kept in separate aquaria with aerated tap water at $10^{\circ} \mathrm{C}$. Only intermoult specimens were used in experiments.

Separation of haemocytes. Semigranular (SG) and granular (G) crayfish cells were separated by density gradient centrifugation by the method of Söderhäll. \& Smith (1983), modified for fresh-water crustaceans. In these experiments $50 \%$ Percoll (Pharmacia AB, Uppsala, Sweden) in $0.15 \mathrm{M} \mathrm{NaCl}$ was used.

Separation of fixed haemocytes for agglutination assay by lectins. To obtain fixed haemocytes one part of haemolymph was directly withdrawn into a syringe containing 2 parts of $3.7 \%$ formaldehyde in $0.15 \%$ $\mathrm{NaCl}$ supplemented with 500 UM SITS (4-acetamido-4 isothiocyanatostilben-2,2-disulfonic acid disodium salt); the fixed haemocytes were separated by Percoll gradient $(50 \%)$ centrifugation $(170 \times g$ for $5 \mathrm{~min})$. Then they were harvested by a Pasteur pipette and postfixed in the same fixative for $30 \mathrm{~min}$ and finally washed with PBS $\left(10 \mathrm{mM} \mathrm{Na}_{2} \mathrm{HPO}_{2}, 10 \mathrm{mM} \mathrm{KH}_{2} \mathrm{PO}_{4}, 0.15 \mathrm{~N}\right.$ $\mathrm{NaCl}, 10 \mu \mathrm{M} \mathrm{CaCl}_{2}, 10 \mu \mathrm{M} \mathrm{MnCl}_{2}, 2.7 \mathrm{mM} \mathrm{KCl}, \mathrm{pH}$ 6.8) 3 times by repeated centrifugation ( $50 \times \mathrm{g}$ for $2 \mathrm{~min}$ ).

Separation of non-fixed haemocytes for direct fluorescence staining. Non-fixed viable haemocytes were isolated by $50 \%$ Percoll gradient centrifugation. One part of the haemolymph was directly withdrawn into a syringe containing 2 parts of anticoagulant buffer $(0.14 \mathrm{M} \mathrm{NaCl}, 0.1 \mathrm{M}$ glucose, $30 \mathrm{mM}$ trisodium citrate, $26 \mathrm{mM}$ citric acid and $10 \mathrm{mM}$ EDTA, pH 4.6) and then separated by Percoll gradient (50\%) centrifugation as above. Harvested cell bands were diluted with anticoagulant buffer and centrifuged to remove Percoll particles $(50 \times g$ for $2 \mathrm{~min}$ ). The resulting cell pellet was carefully resuspended in PBS to yield a cell density of about 10 to $20 \times 10^{4} \mathrm{ml}^{-1}$ and was used for direct fluorescence staining.

Agglutination of fixed haemocytes by different lectins. For agglutination tests $S G$ and $G$ cells which had been fixed in formaldehyde prior to separation were used. The lectins used for this test were as follows: PNA = peanut agglutinin (Arachis hypoge), SBA = soybean agglutinin (Glycine max) and PSA = pea agglutinin (Pisum sativum) all from the Department of Biochemistry, Charles University, Prague, Czechoslovakia; and WGA = wheat germ agglutinin (Triticum vulgaris) and Con $\mathrm{A}=$ concanavalin $\mathrm{A}$ (Canavalis ensiformis) purchased from Phamacia AB, Uppsala, Sweden, and Kemila, Stockholm, Sweden. These lectins were prepared in $0.15 \mathrm{M} \mathrm{NaCl}$ at concentrations of $1.0 \mathrm{mg} \mathrm{ml}^{-1}$ and $200 \mu \mathrm{g} \mathrm{ml}^{-1}$. For each assay $50 \mu \mathrm{l}$ of cell suspension, $50 \mu \mathrm{l}$ of lectin and $50 \mu \mathrm{l}$ of PBS were incubated in glass test tubes for 30 min with gentle rocking $\left(22 \times \min ^{-1}\right)$. To test inhibition of agglutination $50 \mu \mathrm{l}$ of $0.5 \mathrm{M} \alpha$-methyl-D-mannoside (final concentration $0.17 \mathrm{M}$ ) was added instead of PBS.

Staining of haemocytes with FITC-labelled concanavalin A. To prepare cell monolayers pyrogen-free coverslips $(22 \times 22 \mathrm{~mm})$ were placed in Linbro multiwell plates (Flow laboratories, Irvine, Scotland) and $50 \mu \mathrm{l}$ of cell suspension added and incubated for $15 \mathrm{~min}$. FITC-Con A solution (50 $\mu \mathrm{g} \mathrm{ml}^{-1} \mathrm{PBS}$ ) was then added to the cell monolayers and incubated for $30 \mathrm{~min}$ at room temperature (ca 20 to $23^{\circ} \mathrm{C}$ ). After incubation, $3 \mathrm{ml}$ of $3.7 \%$ formaldehyde in $0.15 \mathrm{M} \mathrm{NaCl}$ was added to the well for $30 \mathrm{~min}$ to fix the haemocytes. The haemocyte monolayers were washed with PBS and the fluorescence of the cells observed. The staining patterns of cells were classified into 3 categories; capping, patching and homogeneously stained haemocytes (see Darnel et al. 1986). The inhibitory effect of $\alpha$-methyl-Dmannoside on Con A binding to haemocytes was also investigated. 
Injection of Zymosan into the haemocoele. Zymosan was suspended in $0.15 \mathrm{M} \mathrm{NaCl}\left(250 \mu \mathrm{g} \mathrm{ml}^{-1}\right)$ and washed 3 times by centrifugation using saline to remove free glucans and followed by steam sterilization. Zymosan suspension $(50,1)$ was aseptically introduced into the base of a walking leg of Astacus astacus. As controls, a sham injection of $50 \mu \mathrm{l}$ of $0.15 \mathrm{M} \mathrm{NaCl}$ was used. After injection, crayfish were kept in aquaria at $10^{\circ} \mathrm{C}$. Eleven days later crayfish were bled and the cap formation of $\mathrm{G}$ cells was checked using FITCCon A.

Parasitological investigation of Psorospermium haeckelii-infected crayfish Astacus astacus. Psorospermium haeckelii was described as a parasite of the European crayfish by Haeckel in 1857 (Söderhäll 1988) but the nature of this parasite is still unknown.

Psorospermium haeckelii-infected Astacus astacus were dissected after bleeding and internal organs including alimentary canal, central nervous system, connective tissue, and muscles were digested with

Table 1. In vitro agglutination of fixed semigranular (SG) and granular (G) cells by different lectins in Pacifastacus leniusculus. Agglutination scale $=(-)$ : no agglutination; $(+)$ : weak agglutination; $(++)$ : moderate agglutination; $(+++)$ : strong agglutination. Haemocyte suspension was mixed with PBS instead of lectins for control experiments

\begin{tabular}{|lll|}
\hline Lectins & SG cells & G cells \\
\hline PNA (peanut agglutinin) & - & - \\
SBA (soybean agglutinin) & - & - \\
PSA (pea agglutinin) & + & + \\
WGA (wheat germ agglutinin) & - & - \\
Con A (concanavalin A.) & +++ & +++ \\
Control & - & - \\
Con A + a-methyl-D-mannoside & - & - \\
\hline
\end{tabular}

$0.1 \%$ pepsin (Sigma, 1:60 000) in $0.1 \mathrm{~N} \mathrm{HCl}$ for $1 \mathrm{~h}$ After digestion, undigested materials were washed several times by centrifugation with distilled water and the number of $P$. haeckelii in the sediments estimated.

\section{RESULTS}

\section{Agglutination of fixed haemocytes with lectins}

Five different lectins were used to test their capacity to agglutinate the haemocytes (Table 1). When SG or G cell suspensions were mixed with the Con A solution, a strong agglutination occurred (Fig. 1) using either a high or a low concentration of Con A (final concentrations of 333 and $66 \mu \mathrm{g} \mathrm{ml} \mathrm{m}^{-1}$, respectively). The strong agglutination of haemocytes could be completely inhibited by $\alpha$-methyl-D-mannoside indicating that agglutination reactions were based on lectin binding to the surface carbohydrates of isolated haemocytes. PSA also induced some agglutination, but to a lesser extent than Con $\mathrm{A}$. The other lectins did not cause any clumping of SG or G cells.

Specific binding of Con A to the haemocyte monolayers of Pacifastacus leniusculus was demonstrated using FITC-Con A. First, the fluorescence intensity of haemocytes was investigated using different concentrations of FITC-Con A (final concentrations of 500, 250,100 and $50 \mu \mathrm{g} \mathrm{ml}^{-1}$ ). Using high concentrations of FITC-Con A, an intense fluorescence was observed on the outer surface of haemocytes as well as within the cytoplasm (not shown). This strong fluorescence could not be abolished by the addition of $\alpha$-methyl-Dmannoside (final concentration $0.25 \mathrm{M}$ ) prior to treatment with FITC-Con A, therefore in subsequent experiments the lowest concentration of FITC-Con A

Fig. 1. Haemocytes of Pacifastacus leniusculus. Aggregated granular cells incubated with concanavalin A (final concentration $66 \mu \mathrm{g} \mathrm{ml}^{-1}$ ); bar $=20 \mu \mathrm{m}$

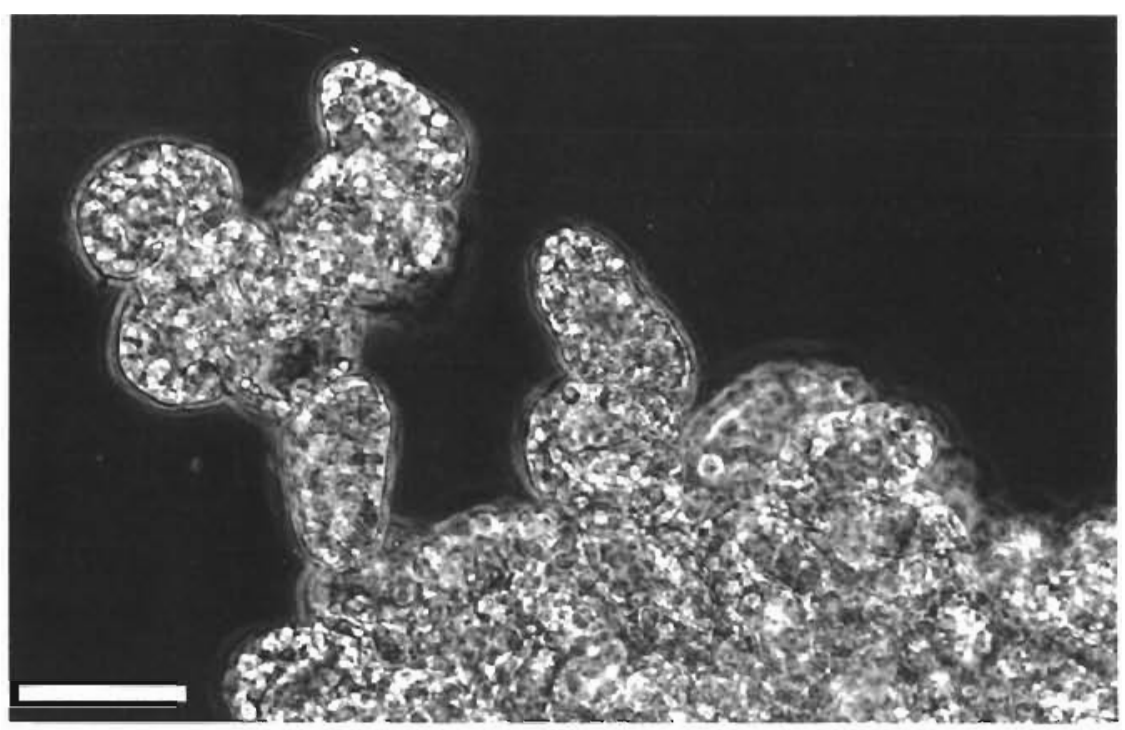




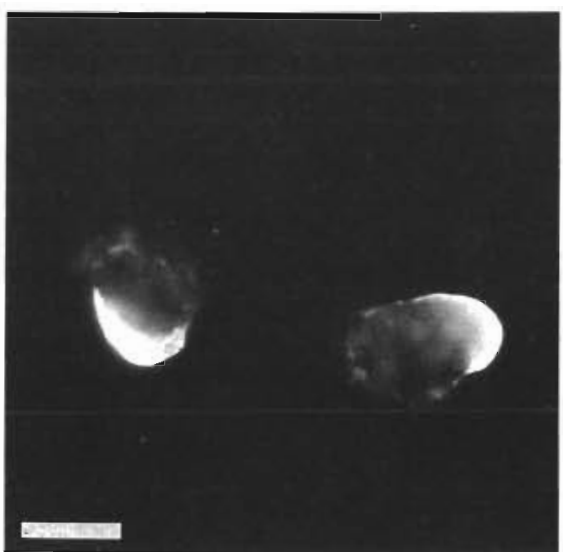

Fig. 2. Granular cells of Pacifastacus leniusculus. Capping of granular cells incubated with FITC-labelled concanavalin A: bar $=20 \mu \mathrm{m}$

(50 $\mu \mathrm{g} \mathrm{ml}^{-1}$ ) was used. Monolayers of $P$. leniusculus SG or $G$ cells exhibited various fluorescence patterns if treated with FITC-Con A. In G cells about $30 \%$ of them showed capping (Fig. 2), whereas nearly all SG cells (ca $95 \%$ ) exhibited patching (Fig. 3) and only a few exhibited a capping-like pattern (Table 2).

Differences in $\mathrm{G}$ cell staining pattern in Psorospermium haeckelii-infected and non-infected Astacus astacus

The average percentage of cap-formed cells (Fig. 4a) in Psorospermium haeckeli-infected crayfish was significantly higher (Table 3) than that of non-infected specimens ( $p<0.01$, Cochran-Cox t-test), whereas the percentage of homogenously stained cells was lower (Fig. 4 c). The number of parasites infecting each specimen varied between individual crayfishes from 14 to 11700 per Astacus astacus. A correlation between the number of parasites and the frequency of cap-forming $G$ cells could not be found. On the other hand, a considerable number of $P$. haeckelii (usually ca $50 \%$ ) were partially or completely encapsulated with brown or blackish brown substances (Fig. 5) which is a result of phenoloxidase activity in host blood cells (Söderhäll 1982) thus indicating that the parasite is recognized by the host.

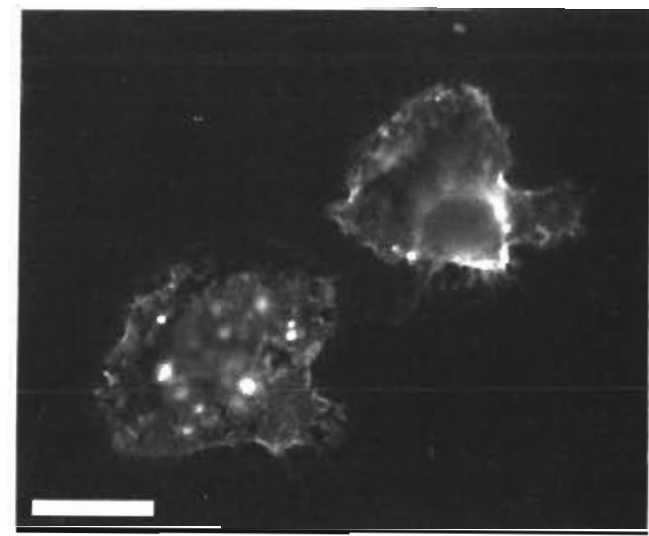

Fig. 3. Semigranular cells of Pacifastacus leniusculus. Patching of semigranular cells incubated with FITC-labelled concanavalin $A_{i}$ bar $=20 \mu \mathrm{m}$

\section{Cap formation of $\mathrm{G}$ cells in Zymosan-injected crayfish Astacus astacus}

Fungal cell walls (i.e. Zymosan) or $\beta-1,3$, -glucans are elicitors of the prophenoloxidase activating system (proPO-system) in crustaceans and insects (Söderhäll 1982). In some experiments Zymosan was injected into the haemocoele of non-infected crayfish and the cap formation of $G$ cells was investigated (Table 4). At $11 \mathrm{~d}$ post-injection $G$ cells derived from Zymosan-injected crayfish exhibited a significantly higher degree of cap formation than saline-injected control crayfish $(p<0.01$, Cochran-Cox t-test). In control crayfish the percentage of cap formation was slightly higher than that of crayfish which received no injection (see Table 3)

\section{DISCUSSION}

In this paper a specific binding of Con A to the surface of isolated haemocytes from 2 crayfish species Astacus astacus and Pacifastacus leniusculus is shown by the in vitro agglutination of haemocytes with Con $A$ and by the staining of haemocytes with FITC-Con A. Specific binding of Con A to haemocyte surfaces has previously been demonstrated in several invertebrates (Yoshino et al. 1979, Yoshino 1981a, b, Renwrantz et al. 1985, Dageförde et al. 1986, Tsing et al. 1989). There-

Table 2. Staining patterns of unfixed haemocytes of Pacifastacus leniusculus using FITC-labelled concanavalin A. Mean percentage calculated from data of 10 crayfish

\begin{tabular}{lcccc|} 
Haemocytes & $\begin{array}{c}\text { Cells } \\
\text { observed }\end{array}$ & $\begin{array}{c}\text { Capping } \\
(\%)\end{array}$ & $\begin{array}{c}\text { Patching } \\
(\%)\end{array}$ & $\begin{array}{c}\text { Homogenous } \\
(\%)\end{array}$ \\
\hline G cells & 2485 & $29.4 \pm 12.9$ & $60.7 \pm 9.9$ & $9.9 \pm 5.3$ \\
SG cells & 2545 & $0.6 \pm 0.6$ & $94.9 \pm 4.2$ & $4.5 \pm 3.9$ \\
\hline
\end{tabular}




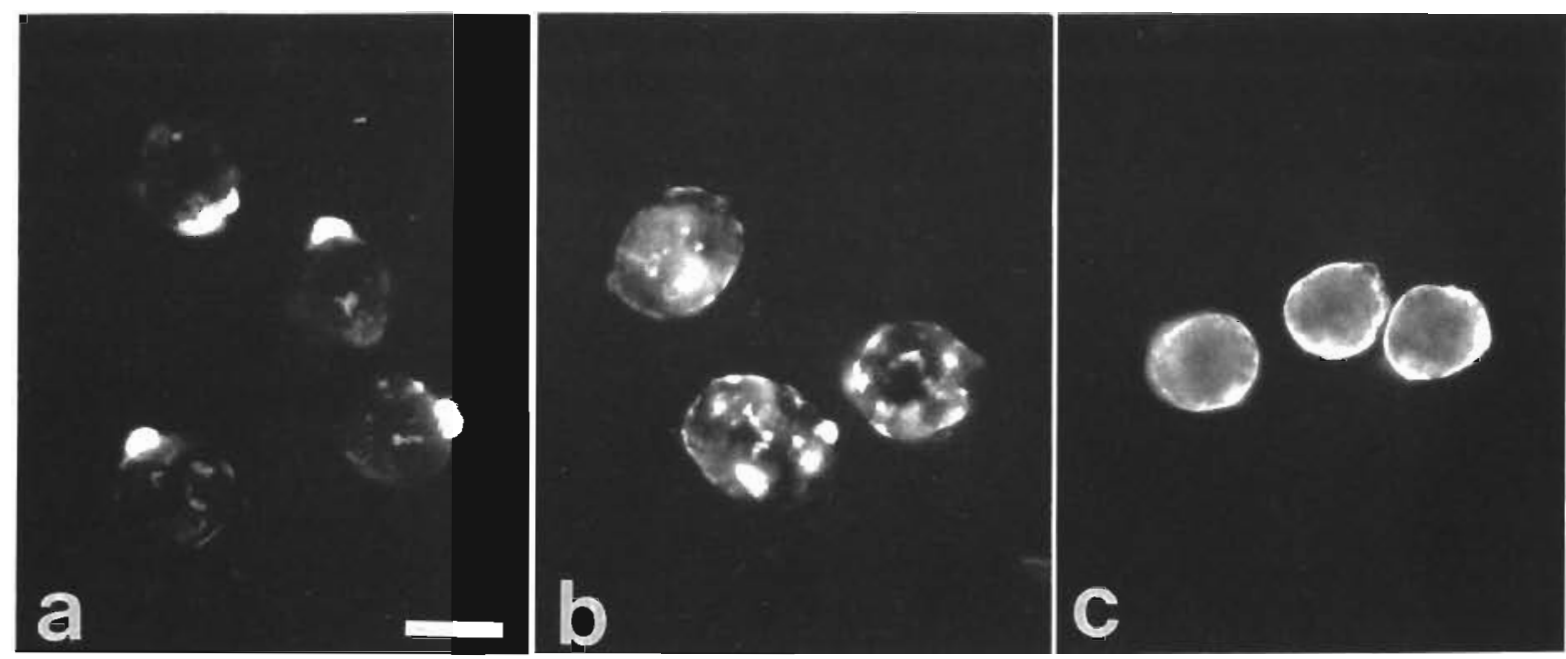

Fig. 4. Granular cells of Astacus astacus. Granular (G) cells treated with FITC-labelled concanavalin A; bar = 20 $\mu \mathrm{m}$. (a) Capping of $G$ cells from Psorospermium haeckelii-infected crayfish; (b) patching of $G$ cells from P. haeckelii-infected crayfish; (c) homogenously stained $G$ cell from non-infected craytish

fore it is possible that invertebrate haemocytes may have mannose residues on the outer surface of the haemocyte membrane. In vertebrates it has been shown that pili of Gram-negative bacteria bind specifically to mannose residues on the surface of mammalian cells to ensure bacterial colonization of the tissues (Ofek et al. 1977, Salit \& Gotschlich 1977, Beachey 1981). If mannose residues are present on crayfish haemocytes they may play a role in trapping and phagocytozing invading bacteria thereby removing them from circulation. In crayfish $G$ cells of both species could exhibit both capping and patching responses to FITC-Con $A$, although the percentage of cap-formed or patch-formed cells varied between individuals.

Capping is a well-known phenomenon in vertebrate lymphocytes which can be observed when antigen or other ligands bind to receptors of the cell membrane and then these receptor-ligand complexes move to certain areas of the cell. Since cytochalasin B or vinblastine can inhibit the capping response it shows that microfilaments and microtubules are involved in the cap formation (Petris 1974).

The frequency of cap-forming G cells was drastically different between Psorospermium haeckelii-infected and non-infected Astacus astacus (Table 4). The percentage of cap-forming $G$ cell of Pacifastacus leniusculus was also higher compared to that of non-infected $A$. astacus. We have shown that all $P$. leniusculus investigated to date are infected with the parasitic fungus Aphanomyces astaci and several melanized hyphae can be found in the cuticle (Söderhäll et al. 1988). In the current experiments we could not compare the frequency of cap formation between cells of parasite-infected and non-infected $P$. leniusculus since plague-free $P$. leniusculus are not obtainable. However, our results may show that G cells of P. leniusculus behave in a manner similar to those from $P$. haeckeliiinfected $A$. astacus. This suggests that the presence of a parasite within the crayfish affects haemocytes, i.e. the haemocytes in some unknown way have been prepared to respond to the parasitic organism. Haemocytes of Drosophila melanogaster also altered their surface properties, i.e. WGA-binding, when parasitized by the eggs of a wasp or implanted with heterospecific tissues (Rizki \& Rizki 1983, Nappi \& Silver 1984). It seems, therefore, that a general property of arthropod haemocytes is that in some way, they are able to alter their haemocyte surfaces if parasitized, suggesting that the cells are activated for defence.

Table 3. Staining patterns of granular haemocytes from Psorospermium haeckeli-infected and non-infected Astacus astacus with FITC-labelled concanavalin A. Mean percentage calculated from data of 10 crayfish

\begin{tabular}{|lcccc|}
\hline & $\begin{array}{c}\text { Cells } \\
\text { observed }\end{array}$ & $\begin{array}{c}\text { Capping } \\
(\%)\end{array}$ & $\begin{array}{c}\text { Patching } \\
(\%)\end{array}$ & $\begin{array}{c}\text { Homogenous } \\
(\%)\end{array}$ \\
\hline $\begin{array}{l}\text { P. haeckelii-infected } \\
\text { Non-infected }\end{array}$ & 4841 & $48.4 \pm 21.6$ & $43.7 \pm 18.1$ & $8.0 \pm 6.5$ \\
\hline
\end{tabular}




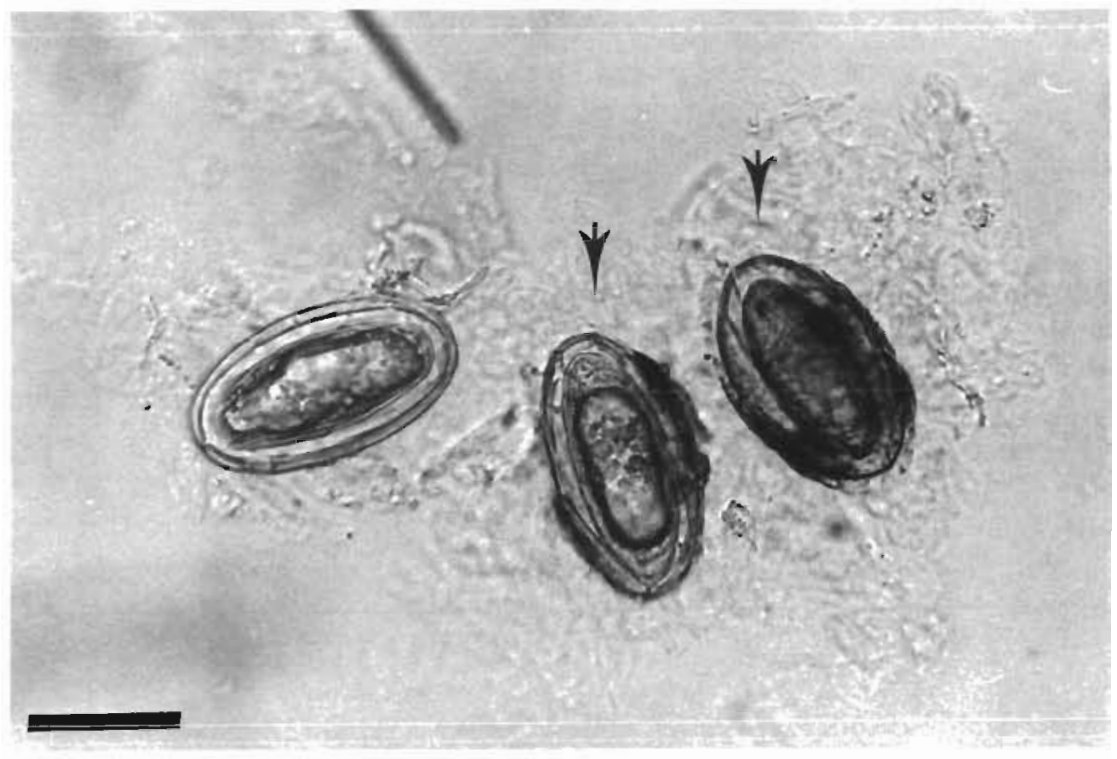

Fig. 5. Partially and non-encapsulated Psorospermium haeckelii from digested internal organs of Astacus astacus (ấrows show encapsuiateù parasites); bar $=50 \mu \mathrm{m}$

Table 4. Staining patterns of granular haemocytes of Astacus astacus using FITC-labelled concanavalin $A$ in Zymosaninjected and saline-injected crayfish. Mean percentage calculated from data of 6 crayfish

\begin{tabular}{|lcccc|}
\hline Injection & $\begin{array}{c}\text { Cells } \\
\text { observed }\end{array}$ & $\begin{array}{c}\text { Capping } \\
(\%)\end{array}$ & $\begin{array}{c}\text { Patching } \\
(\%)\end{array}$ & $\begin{array}{c}\text { Homogenous } \\
(\%)\end{array}$ \\
\hline $\begin{array}{l}\text { Zymosan } \\
\text { Saline }\end{array}$ & 2823 & $50.8 \pm 7.4$ & $39.4 \pm 7.1$ & $9.9 \pm 3.3$ \\
\hline
\end{tabular}

In preliminary experiments, it has been shown that cap formation of $\mathrm{G}$ cells is influenced by the length of time, cell monolayers are incubated prior to FITC-Con A addition. Furthermore, the degree of spreading during cell monolayer preparation may be an important factor for cap formation. The results may show that the mobility of the ligand within the cell membrane in $G$ cells is different between parasite-infected crayfish and non-infected, healthy crayfish. This active mobility of $G$ cell-membrane could also be reproduced by injection of Zymosan into the haemocoele of crayfishes (Table 4). Zymosan contains $\beta$-1,3-glucans which are elicitors of proPO-system activation in arthropods (Söderhäll 1982) and these carbohydrates also release the proPO-system from the haemocytes by regulated exocytosis (for review see Johansson \& Söderhall $1989 \mathrm{~b}$ ). Thus injection of Zymosan can be used to mimic the effects of a fungal infection (Persson et al. 1987 a). Recently, we have shown that an injection of Zymosan causes a drastic decrease in the total haemocyte count in Pacifastacus leniusculus lasting about 6 to $12 \mathrm{~h}$, and that this injection triggered the growth of Aphanomyces astaci hyphae within the host cuticle (Persson et al. 1987a), and as a consequence P. lenius- culus died from its own crayfish plague. This strongly suggests that the number of haemocytes (total haemocyte count) is an important parameter in the hosts defence capacity. In this paper, we also show that when crayfish are infected with a parasite the surface properties, i.e. Con A-binding, are significantly altered since cap-forming cells are more abundant in parasiteinfected than in non-infected crayfish. Since cap formation in vertebrate lymphocytes is often the first sign of an immune response, it may be that capping in crayfish haemocytes is also the first sign that host cells are activated and ready to be engaged in cellular defence activities.

Acknowledgements. This work has been financed by grants from the Swedish Agricultural Research Science Council, the Fishery Board of Sweden, and the Swedish Natural Science Research Council.

\section{LITERATURE CITED}

Beachey, E. H. (1981). Bacterial adherence adhesin-receptor interactions mediating the attachment of bacteria to mucosal surface. J. infect. Dis. 143: 325-345

Dageförde, S., Schmucker, A., Renwrantz, L. (1986). Capping of cell. surface receptors on blood cells from the molluscs Helix pomatia (Gastropoda) and Mytilus edulis (Lamellibranchiata). Eur. J. Cell Biol. 41. 113-120

Darnell, J., Lodish, H., Balimore, D. (1986). Molecular cell biology. Scientific American Books, New York

Haeckel, E. (1857). Ueber die Gewebe des Flusskrebses, Arch. Anat. Physiol. Med., p. 561-562

Johansson, M. W., Söderhäll, K. (1985). Exocytosis of the prophenoloxiddse activating system from crayfish haemocytes. J. comp. Physiol. (Sect. B) 156: 175-181

Johansson, M. W., Soderhäll, K. (1988). Isolation and purification of a cell adhesion factor from crayfish blood cells. J. Cell Biol. 106: 1795-1804 
Johansson, M. W., Söderhäll, K. (1989a). A cell adhesion factor from crayfish haemocytes has degranulating activity towards crayfish granular cell. Insect Biochem. 19 $183-190$

Johansson, M. W., Söderhäll, K. (1989b). Cellular immunity in crustaceans and the proPO system. Parasitology Today 5 $171-176$

Johansson, M. W., Södęrhäll, K. (1989c). A peptide containing the cell adhesion sequence RGD can mediate degranulation and cell adhesion of crayfish granular haemocytes in vitro. Insect Biochem. 19: 575-579

Kobayashi, M., Johansson, M. W., Söderhäll, K. (1990). The 76 $\mathrm{kD}$ cell adhesion factor from crayfish haemocytes promotes encapsulation in vitro. Cell Tissue Res. 260: 13-18

Lackie, A. M. (1988). Haemocyte behaviour. Adv. Insect Physiol. 21: $85-178$

Nappi, A. J., Christensen, B. M. (1986). Hemocyte cell surface changes in Aedes aegypti in response to microfilariae of Dirofilaria immitis. J. Parasit. 72: 875-879

Nappi, A. J., Silver, M. (1984). Cell surface changes associated with cellular immune reactions in Drosophila. Science 225 $1166-1168$

Ofek, I., Mirelman, D., Sharon, N. (1977). Adherence of Escherichia coli to human mucosal cells mediated by mannose receptors. Nature, Lond. 265: 623-625

Persson, M., Cerenius, L., Söderhäll, K. (1987a). The influence of haemocyte number on the resistance of the freshwater crayfish, Pacifastacus leniusculus Dana, to the parasitic fungus Aphanomyces astaci. J. Fish Dis. 10: 471-477

Persson, M., Vey, A., Söderhäll, K. (1987b). Encapsulation of foreign particles in vitro by separated blood cells from crayfish, Astacus leptodactylus. Cell Tissue Res. 247: $409-417$

Petris, S. (1974). Inhibition and reversal of capping by cytochalasin B, vinblastine and colchicine. Nature, Lond. 250: $54-56$

Ratcliffe, N. A., Rowley, A. F. (1979). Role of haemocytes in defence against biological agents. In: Gupta, A. P. (ed.) Insect haemocytes. Cambridge University Press, Cambridge, p. 331-413

Renwrantz, L., Daniels, J., Hansen, P.-D. (1985). Lectin-binding to hemocytes of Mytilus edulis. Devl. comp. Immun., N.Y 9: 203-210

Rizki, T M., Rizki, R. M. (1983). Blood cell surface changes in

Responsible Subject Editor: Dr J. E. Stewart, Dartmouth, N.S. Canada
Drosophila mutants with melanotic tumors. Science 220: $73-75$

Salit, I. E., Gotschlich, E. C. (1977). Type I Escherichia coli pili: characterization of bunding to monkey kidney cells. J. exp Med. 146: 1182-1194

Smith, V. J., Söderhäll, K. (1983). Induction of degranulation and lysis of haemocytes in the freshwater crayfish. Astacus astacus by components of the prophenoloxidase activating system in vitro. Cell Tissue Res. 233: 295-303

Söderhäll, K. (1982). The Prophenoloxidase activating system and melanization-a recognition mechanism of arthropods. A review. Devl. comp. Immun., N.Y 6: 609-611

Söderhäll, K. (1988). Fungal parasites and other diseases on freshwater crayfish. In: Kavanen, J., Lappalainen, R. (eds.) Raputalous 2000. Kenski. Suomen Kalastuspiirn Kalastustoimisto Tiedotuss, Jyvaskyla, p. 23-46

Söderhäll, K., Johansson, M. W., Smith, V. J. (1988). Internal defence mechanism. In: Holdich, D. M., Lowery, R. S. (eds.) Freshwater crayfish: biology, management and exploitation. Croom Helm Ltd., London, p. 213-235

Söderhäll, K., Smith, V. J. (1983). Separation of the haemocyte population of Carcinus maenas and other marine decapods, and prophenoloxidase distribution. Devl. comp. Immun., N.Y 7: 229-239

Söderhäll, K., Smith, V. J. (1986). The prophenoloxidase activating cascade as a recognition and defense system in arthropods. In: Gupta, A. P. (ed.) Humoral and cellular immunity in arthropods. John Wiley and Sons, New York, p. 251-285

Tsing, A., Arcier, J.-M., Brehelin, M. (1989). Hemocytes of penaeid and palaemonid shrimps: morphology, cytochemistry, and hemograms. J. Invertebr. Path. 53: 64-77

Yoshino, T P. (1981a). Concanavalin A-induced receptor redistribution on Biomphalaria glabrata haemocytes: characterization of capping and patching response. J. Invertebr. Path. 38: 102-112

Yoshino, T. P. (1981b). Comparison of concanavalin A-reactive determinants on hemocyts of two Biomphalaria glabrata snail stocks: receptor binding and redistribution. Devl. comp. Immun., N.Y. 5: 229-239

Yoshino, T. P., Renwrantz, L., Cheng, T. C. (1979). Binding and redistribution of surface membrane receptors for concanavalin A on oyster hemocytes. J. exp. Zool. 207: $439-450$

Manuscript first received: October 13, 1989

Revised version accepted: July 27, 1990 